\title{
Integration of IncRNA-miRNA-mRNA reveals novel insights into oviposition regulation in honey bees
}

\author{
Xiao Chen ${ }^{1}$, Ce Ma ${ }^{2}$, Chao Chen ${ }^{1}$, Qian Lu ${ }^{2}$, Wei Shi ${ }^{\text {Corresp.. }}{ }^{1}$, Zhiguang Liu ${ }^{1}$, Huihua Wang ${ }^{1}$, Haikun Guo \\ 1 Institute of Apicultural Research, Chinese Academy of Agricultural Sciences, Beijing, China \\ 2 Novogene Co., LTD, Tianjin, China \\ Corresponding Author: Wei Shi \\ Email address: xiaochen1984@cau.edu.cn
}

\section{Background}

The honey bee (Apis mellifera) is a highly diverse species commonly used for honey production and pollination services. The oviposition of honey bee queen affects the development and overall

performance of the colony. To investigate the ovary activation and oviposition processes on a molecular level, a genome-wide analysis of IncRNAs, miRNAs and mRNAs expression in ovaries of the queens was performed to screen for differentially expressed coding and noncoding RNAs. Further analysis identified relevant candidate genes or RNAs.

\section{Results}

The analysis of the RNA profiles in different oviposition phase of the queens revealed that 740 IncRNAs, 81 miRNAs and 5481 mRNAs were differently expressed during the ovary activation; 88 IncRNAs, 13 miRNAs and 338 mRNAs were differently expressed during the oviposition inhibition process; and finally, 100 IncRNAs, 4 miRNAs and 497 mRNAs were differently expressed during the oviposition recovery process. In addition, functional annotation of differentially expressed RNAs revealed several pathways that are closely related to oviposition, including hippo, MAPK, notch, Wnt, mTOR, TGF-beta and FoxO signaling pathways. Furthermore, in the QTL region for ovary size, 73 differentially expressed genes and 14 differentially expressed IncRNAs were located, which are considered as candidate genes affecting ovary size and oviposition. Moreover, a core set of genes served as bridges among different miRNAs were identified through the integrated analysis of IncRNA-miRNA-mRNA network.

\section{Conclusion}

The observed dramatic expression changes of coding and noncoding RNAs suggest that they may play a critical role in honey bee queens' oviposition. The identified candidate genes for oviposition activation and regulation could serve as a resource for further studies of genetic markers of oviposition in honey bees. 


\section{Integration of IncRNA-miRNA-mRNA reveals novel insights into}

\section{2 oviposition regulation in honey bees}

3 Xiao Chen ${ }^{1}, \mathrm{Ce} \mathrm{Ma}^{2}$, Chao Chen ${ }^{1}$, Qian $\mathrm{Lu}^{2}$, Wei Shi ${ }^{1} \square$, Zhiguang Liu ${ }^{1}$, Huihua Wang ${ }^{1}$, Haikun

$4 \mathrm{Guo}^{1}$

$5{ }^{1}$ Institute of Apicultural Research, Chinese Academy of Agricultural Sciences, Xiangshan,

6 100093, Beijing, China

$7 \quad 2$ Novogene Co., LTD, Wuqing Entrepreneurial Base, 301700, Tianjin, China

$8 \square$ Corresponding author:

9 Wei Shi

10 Haidian District Xiangshan Beigou No.1, Beijing, 100093, China

11 E-mail: shiweibri@126.com; xiaochen1984@cau.edu.cn 
12

13

14

\section{Abstract}

\section{Background}

The honey bee (Apis mellifera) is a highly diverse species commonly used for honey production and pollination services. The oviposition of honey bee queen affects the development and overall performance of the colony. To investigate the ovary activation and oviposition processes on a molecular level, a genome-wide analysis of lncRNAs, miRNAs and mRNAs expression in ovaries of the queens was performed to screen for differentially expressed coding and noncoding RNAs. Further analysis identified relevant candidate genes or RNAs.

\section{Results}

The analysis of the RNA profiles in different oviposition phase of the queens revealed that 740 lncRNAs, 81 miRNAs and 5481 mRNAs were differently expressed during the ovary activation; 88 lncRNAs, 13 miRNAs and 338 mRNAs were differently expressed during the oviposition inhibition process; and finally, 100 lncRNAs, 4 miRNAs and 497 mRNAs were differently expressed during the oviposition recovery process. In addition, functional annotation of differentially expressed RNAs revealed several pathways that are closely related to oviposition, including hippo, MAPK, notch, Wnt, mTOR, TGF-beta and FoxO signaling pathways. Furthermore, in the QTL region for ovary size, 73 differentially expressed genes and 14 differentially expressed lncRNAs were located, which are considered as candidate genes affecting ovary size and oviposition. Moreover, a core set of genes served as bridges among different miRNAs were identified through the integrated analysis of lncRNA-miRNA-mRNA network.

\section{Conclusion}

The observed dramatic expression changes of coding and noncoding RNAs suggest that they may play a critical role in honey bee queens' oviposition. The identified candidate genes for oviposition activation and regulation could serve as a resource for further studies of genetic markers of oviposition in honey bees. 


\section{Introduction}

The honey bee (Apis mellifera) is a highly diverse species commonly used for honey production and pollination services. The oviposition of honey bee queen is a complex behavior and it is crucial for the reproductive success and affects the development of the colony (Woodward 2010). However, most reproductive traits are complex in terms of their genetic architecture, present low heritability and are sex-limited (Manfredini et al. 2015; Mello et al. 2014). Thus, it is hard to be improved by using traditional selection methods, eg. selective breeding. With the development of molecular technologies, new approaches applied to improve reproductive traits and other complex traits, such as marker-assisted selection (MAS) and genomic selection (Kramarenko et al. 2014; Spötter et al. 2012). These methods have been used widely in domestic animals for years. However, in honey bees these strategies became popular only in recent years (Spötter et al. 2012). A better understanding of the genetic architecture of honey bee will help scientists develop a better strategy for acceleration of the genetic improvement of the reproductive traits.

Honey bees provide an excellent model for oviposition molecular studies. The fact that queens specialize in oviposition, leaving other tasks, for example brood caring, to sterile female workers (Koeniger 2008), potentially reduces the complexity of studying reproductive traits. The process of queens' ovary activation is so fast that queens start to lay eggs around 3 days after the mating (Gary 1992). In addition, the activity of queens' oviposition is constantly adjusted throughout the year in order to change the colony's strength according to the environmental conditions (Schneider 1992). Such adjustments can be accomplished within a short period (Koeniger 2008), which guarantees colonies' survival and development in the context of dramatic changes of internal and external conditions. Molecular studies have shown that these changes and regulations are associated with profound differences in coding gene expressions (Lago et al. 2016; Pandey \& Bloch 2015) such as ecdysone receptor ( $E c R)$, mushroom body large-type Kenyon cell-specific protein-1 $(M B L K-1)$, ecdysone-induced protein $74(E 74)$ and ultraspiracle (Usp) (Pandey \& Bloch 2015).

Recently, the characterization of non-coding RNAs, microRNAs (miRNAs) and long non-coding 
65

66

67

RNAs (lncRNAs) has become a fruitful area of animals and plants researches. In previous works, several miRNAs, such as bantam, miR-184 and miR-315, have been reported to play important roles in modulating tissue patterns, cell differentiation, ovary development and caste determination in honey bees (Ashby et al. 2016; Macedo et al. 2016). Additionally, miR-14 and miR-8 have been suggested to be associated with juvenile hormones $(J H)$ and ecdysteroids $(E c)$, which play key roles in ovary development and other reproductive behaviors in honey bees (Boecking et al. 2000; Flatt et al. 2005; Goodman \& Cusson 2012; Hartfelder \& Emlen 2005; Hoover et al. 2003; Riddiford 1994; Wyatt \& Davey 1996). The other highly expressed noncoding RNAs, lncRNAs, also has a great influence in biological processes, such as cell differentiation, development, immune responses and tumourigenesis (Okazaki et al. 2002; Ota et al. 2004; Wilusz et al. 2009). Moreover, Necsulea et al. found lncRNAs that were preferentially expressed in animals' ovary (Necsulea et al. 2014), and lincRNAs (long intergenic non-coding RNAs) were observed by Jayakodi et al. (2015) in Apis mellifera to be expressed preferentially in ovary tissue. Furthermore, lncRNAs can be targeted by miRNAs and thus regulate the expression of mRNAs (Fan et al. 2015; Gong et al. 2016). Therefore, it is valuable to investigate the critical role of lncRNAs, miRNAs and lncRNA-miRNA-mRNA network in honey bee queens' oviposition.

In order to identify differentially expressed RNAs in ovary activation and oviposition regulation process, we first examined the lncRNA, miRNA and mRNA expression profiles in ovaries of virgin queens, egg-laying queens, egg-laying inhibited queens and egg-laying recovered queens using high throughput sequencing method, then compared the RNA expression patterns to help identify candidate genes and/or RNAs that contribute to oviposition activation and regulation. Next, we selected candidate genes or RNAs which may have high effects in regulating ovary size and oviposition by assign the differently expressed RNAs into a QTL for ovary size. Furthermore, the lncRNA-miRNA-mRNA network was constructed to explore the interaction among different RNAs.

\section{Materials and methods}


92

93

94

95

96

97

98

99

100

101

102

103

104

105

106

107

108

109

110

111

112

113

114

115

116

\section{Ethics statement}

The apiaries for honey bee sample collection were maintained by Institute of Apicultural Research, Chinese Academy of Agricultural Sciences (IAR, CAAS), Beijing, China. No specific permits were required for the described studies.

\section{Sampling}

All samples were obtained from Apis mellifera ligustica honeybee colonies. In June 2015, 20 sister queens from a single source colony were reared using standard beekeeping techniques (Harbo 1986). Five days before the emergence, the queens were transferred to an incubator at $36^{\circ} \mathrm{C}$ and kept individually in plastic vials. One day old, the queens were marked and each was introduced to her own nucleus colony. The strength of each colony was similar. The entrance of each hive was covered with a queen excluder that confined the queen within the hive but allowed workers to exit and enter.

Six day old queens were randomly assigned to one of the four groups representing different treatments: (1) virgin queens $(n=5) ;(2)$ egg-laying queens $(n=5)$ that successfully laid eggs after instrumental insemination; (3) egg-laying inhibited queens $(n=5)$ consisting of egg-laying queens caged in a small cage and kept inside the original hive for 7 days; (4) egg-laying recovery queens $(n=5)$, which were first caged in a small cage inside the original hive for 7 days to prevent them from egg-laying and then released into their individual colonies for 24 hours. All egg-laying recovery queens were able to lay eggs within the 24 hours after their release from the small cages.

Ovaries of all queens in the four groups were extirpated and stored at $-80{ }^{\circ} \mathrm{C}$ at the end of the treatment. For instrumental insemination, the source and quantity of the semen was the same for all mated queens. Each sample consisted of the ovary from a single queen. Three samples per treatment group were used for RNAseq (total $=12$ samples).

\section{RNA extraction and library preparation for sequencing}

Total RNA was extracted from ovary samples using Trizol reagent (Invitrogen, Carlsbad, CA, 
117 USA) according to the manufacturer's instructions. The purity of RNA was checked using the 118 NanoPhotometer spectrophotometer (IMPLEN, CA, USA), and the concentration was measured 119 using Qubit RNA Assay Kit in Qubit 2.0 Flurometer (Life Technologies, CA, USA). The 120 integrity of RNA was assessed using the RNA Nano 600Assay Kit of the Agilent Bioanalyzer 1212100 system (Agilent Technologies, CA, USA).

122 LncRNA and mRNA library preparation was carried out using NEBNext ${ }^{\circledR}$ Ultra ${ }^{\mathrm{TM}}$ Directional 123 RNA Library Prep Kit for Illumina ${ }^{\circledR}$ (NEB, USA) following manufacturer's recommendations. 124 Paired-end reads of $150 \mathrm{bp}$ were generated using the Illumina Hiseq 4000 platform. After quality 125 control, paired-end clean reads were aligned to the reference genome (Amel_4.5) using TopHat 126 v2.0.9. Transcripts were assembled and annotated using Cufflinks 127 (http://cufflinks.cbcb.umd.edu/). The known mRNAs and lncRNAs were identified according to 128 the annotation of Apis mellifera genome sequence (Amel_4.5). The remaining transcripts were used to screen for putative lncRNAs using the following criteria: (1) length $\geq 200 \mathrm{bp}$; (2) exon number $\geq 2$; (3) sequencing coverage $\geq 3$; (4) identified in at least two samples. The transcripts meeting the above criteria were further filtered by removing known non-lncRNA transcripts. Then, the transcripts that passed the filters were evaluated for coding potential using CPC (0.9-r2) (Kong et al. 2007) and Pfam-scan (v1.3) (Punta et al. 2012). Only those without coding potential were categorized as novel lncRNAs.

Small RNA library preparation was carried out using NEBNext@ Multiplex Small RNA Library Prep Set for Illumina ${ }^{\circledR}$ (NEB, USA) following manufacturer's recommendations. Single-end reads of 50bp were generated using the Illumina Hiseq 2500 platform. After quality control, the clean reads were mapped to reference sequence (Amel_4.5) applying Bowtie (Langmead et al. 2009). Mapped reads were used to identify known miRNAs using miRBase 20.0 (Griffiths-Jones 2010). Novel miRNAs were predicted with miREvo (Ming et al. 2012) and mirdeep2 (Friedländer et al. 2012) through exploring the characteristic hairpin structure, Dicer cleavage sites and minimum free energy. 
143 All the sequencing data are available through the GEO database with accession number 144 GSE93028.

145

146

147

\section{Differentially expressed IncRNAs, miRNAs and mRNAs identification and clustering} analysis

Differentially expressed (DE) lncRNAs, miRNAs and mRNAs (Benjamini \& Hochber method corrected p-value $<0.05)$ were identified using DESeq R package (1.8.3) for each of the following comparisons: (1) egg-laying queens vs. virgin queens (ovary activation process); (2) egg-laying inhibited queens vs. egg-laying queens (oviposition inhibition process); (3) egglaying recovery queens vs. egg-laying inhibited queens (oviposition recovery process). Furthermore, the expression of each RNA type was analyzed with unsupervised hierarchical clustering with the R package of "pheatmap". To do unsupervised hierarchical clustering, firstly, the expression of RNA was normalized. For normalization of lncRNA and mRNA, the following formula was used: $\mathrm{FPKm}=\log _{10} \mathrm{FPKM}+1$. For normalization of miRNA, the following formula was applied: $\mathrm{TPm}=\log _{10} \mathrm{TPM}+1$ (TPM, transcripts per kilobase million). Then the euclidean distance was used to measure the degree of similarity between the expression profiles of samples. The method in the package to cluster distance is "complete".

\section{Prediction of IncRNA and miRNA target genes}

The potential trans role of lncRNAs (acting on non-neighboring genes) can be assessed by correlating expression levels between lncRNAs and mRNAs. The trans role of lncRNAs in coding genes was examined based on the expression correlation coefficient (Pearson correlation $\geq 0.95$ or $\leq-0.95$ ). To predict miRNAs targets, we searched for the targets in the 3 'UTR of genes models. For genes lacking a predicted 3'UTR, the region 1000bp downstream of the stop codon were included. The prediction was performed by Miranda with the following parameter: free energy $<-10 \mathrm{kcal} / \mathrm{mol}$ and score $>140$ (Enright et al. 2003).

\section{Functional enrichment analysis}


168

169

170

171

172

173

174

175

176

177

178

179

180

181

182

183

Apis mellifera gene set was annotated based on the corresponding Drosophila melanogaster orthologues and catergorized by their biological functions. Gene annotation was done by a homology-based method. Apis mellifera CDS sequences were blasted against the Drosophila melanogaster peptide sequences (Ensembl database Release 74) using the comment "-p blastx m8 -e 1e-5-F F". The minimum peptide alignment must be more than 50 aa. The correspondence relationship of Apis mellifera genes and ontology categories was decided by the hit with the best alignment score. Gene ontology (GO) enrichment analysis with Drosophila melanogaster reference gene set was implemented by GOseq R package (Young et al. 2012). KEGG pathways analysis was performed using KOBAS to determine the involvement of genes in different biological pathways (Mao et al. 2005).

Chromosomal localization of DE IncRNAs and mRNAs in quantitative trait locus (QTL) for ovary Size

The localization of the DE lncRNAs and DE mRNAs on Apis mellifera chromosomes was accessed from NCBI database (Amel_4.5). Each RNA location was estimated in centimorgans and was compared with the location of a significant QTL previously identified for ovary size. This QTL locates on chromosome 11 between the position 8.9 Mb and 12.2 Mb (Graham et al. 2011; Linksvayer et al. 2009). Genes or RNAs which locate within the QTL confidence intervals were accepted as candidate genes for ovary size and potential candidate genes for oviposition.

\section{Construction of IncRNA-miRNA-mRNA network}

To construct lncRNA-miRNA-mRNA network, we first selected lncRNAs which were predicted to act as miRNA targets or decoys by Fan's methods (Fan et al. 2015). Next, to define the miRNA-mRNA relationships, the Pearson correlation coefficient value between a miRNA and its target mRNA was calculated, and strongly correlated miRNA-mRNA pairs (the absolute value of greater 0.8 ) were selected (either positive or negative). To construct the network, each DE RNA node must be either in a lncRNA-miRNA pair or in a miRNA-mRNA pair. The nodes in the network consisted of miRNAs, lncRNAs acting as miRNA targets, lncRNAs acting as miRNA 
194 decoys, mRNAs acting as miRNA targets. The network was visualized using Cytoscape (version 195 3.4.0) (Smoot et al. 2011).

196

197

198

199

200

201

202

203

204

205

206

207

208

209

210

211

212

213

214

215

216

217

218

219

\section{Real time PCR}

In order to confirm sequencing results, the expression of 5 lncRNAs, 5 mRNAs and 5 miRNAs were validated by real time PCR using the same 12 ovary samples used for sequencing. Following total RNA extraction, ovarian samples were reversely transcribed to generate cDNA. For cDNA synthesis of lncRNA and mRNA, an M-MLV FIRST STRAND KIT (Invitrogen, Shanghai, China) and an oligo (dT)18 primer were used in a reverse transcription reaction of 20 $\mu 1$, following the supplier's instructions. For miRNA cDNA synthesis, a miRcute miRNA cDNA synthesis kit (Tiangen biotech (Beijing) Co.,LTD) was used. In brief, E.coli Poly(A) Polymerase was used to add poly(A) tail at 3' end and then Oligo(dT)-Universal tag was used in a reverse transcription reaction following the supplier's instructions. Two microliters of each cDNA was subjected to PCR amplification using specific primers (Supplemental Table S1). PCR efficiency of each gene was estimated by standard curve calculation using four points of cDNA serial dilutions. Cycle threshold $(C t)$ values were transformed to quantities using the comparative $C t$ method, setting the relative quantities of virgin queens group for each gene to 1 (quantity=10$\Delta \mathrm{Ct} / \mathrm{slope})$. Data normalization of lncRNA and mRNA were carried out using the Actin reference gene. Data normalization of miRNA was carried out using the U6 reference gene. The correlation between the results of sequencing and PCR was calculated using correlation test.

\section{Results}

\section{Genome-wide identification of DE IncRNAs, mRNAs and miRNAs from honey bee queens}

Sequencing of all lncRNA and mRNA libraries generated 1,243,644,174 raw paired-end reads with a length of 150 bases, resulting in a total of 16.7 gigabases. Sequencing of all miRNA libraries generated $152,659,565$ raw single-end reads with a length of 50 bases, resulting in a total of 7.631 gigabases. The whole expression profiles of lncRNAs, miRNAs and mRNAs of ovaries at four different conditions are presented in Fig. 1. From the expression profiles, DE 
220 IncRNAs, mRNAs and miRNAs were discriminated between different groups (Table 1 and 221 Supplemental Table S2). 740 lncRNAs, 5481 mRNAs and 81 miRNAs were differentially 222 expressed in ovary activation process (egg-laying queens vs. virgin queens). 88 lncRNAs, 338 223 mRNAs and 13 miRNAs were differentially expressed in oviposition inhibition process (egg224 laying inhibited queens vs. egg-laying queens). 100 lncRNAs, 497 mRNAs and 4 miRNAs were differentially expressed in oviposition recovery process (egg-laying recovery queens vs. egglaying inhibited queens). A summary of the up-/down-regulated information is shown in Table 1.

\section{GO and Pathway enrichment analysis}

228 Functional annotation analysis of target genes of the DE lncRNAs, miRNA and mRNA was performed to identify GO terms and KEGG pathways with higher confidence (Supplemental Table S3, S4 and S5). Because GO terms and pathways enriched with the DE lncRNAs, miRNA and mRNAs were similar to each other, here we only describe the enrichment results of DE mRNAs. In the ovary activation process, most of the enriched GO_BP terms of DE mRNAs were involved in tissue development, energy producing and hormone biosynthesis and metabolism, such as oocyte microtubule cytoskeleton polarization, fatty acid oxidation, neurotrophin signaling pathway, ecdysteroid catabolic process (Supplemental Table S3). In the oviposition inhibition process, contrary to the ovary activation process, several GO terms were not enriched, but enrichment occurred again when oviposition recovered, such as cellular response to transforming growth factor beta stimulus, positive regulation of cyclase activity, post-embryonic hemopoiesis, larval lymph gland hemopoiesis, eye pigment biosynthetic process, and compound eye cone cell fate commitment (Supplemental Table S3).

DE mRNAs enrichment $(\mathrm{p}<0.05)$ was seen in KEGG pathways (Supplemental Table S3).

242 Several pathways were both enriched in ovary activation and oviposition regulation process, namely glycerolipid metabolism, glycerophospholipid metabolism, hippo signaling pathway fly, inositol phosphate metabolism, MAPK signaling pathway - fly, neuroactive ligand-receptor interaction, notch signaling pathway, phosphatidylinositol signaling system and Wnt signaling 
246 pathway (Table 2).

247 Chromosomal localization of DE IncRNAs and mRNAs in QTL region for ovary size

248 If the differentially expressed lncRNAs and mRNAs were found located within the confidence 249 interval of the QTL for ovary size, they could be regarded as candidate genes for ovary size and 250 potential candidate genes for oviposition. In this way, 73 candidate genes and 14 lncRNAs 251 (Supplemental Table S6) were identified.

\section{Construction of the IncRNA-miRNA-mRNA network}

253 The bioinformatic analysis predicted that 469 lncRNAs were targeted by 69 miRNAs and 117 254 lncRNAs acted as decoys to 31 miRNAs. The transcriptome network was constructed based on 255 the lncRNA-miRNA and the miRNA-mRNA relationship pairs. The resulting network consists 256 of 229 lncRNA-miRNA pairs and 225 miRNA-mRNA pairs (Supplemental Fig.S1 and Table S7).

257 To further investigate the potential candidate genes and RNAs for ovary activation and 258 oviposition, a reproductive associated network was constructed containing the DE miRNAs and

259

260

261

262

263

264

265

266

267

268

269 mRNAs which played specific or suspected roles in reproduction, and the DE lncRNAs and mRNAs located in the QTL region for ovary size. The network was constructed with 105 lncRNA-miRNA pairs and 83 miRNA-mRNA pairs, consisted of 105 lncRNAs, 25 miRNAs and 74 mRNAs (Fig. 2 and Supplemental Table S8).

\section{Validation of RNA-Seq data by real time PCR}

In order to validate the sequencing results, the expression of 5 lncRNAs, 5 mRNAs and 5 miRNAs were tested by using real time PCR with the same RNA samples used for sequencing (Supplemental Table S1). The expression profiles of these genes/RNAs detected by real time PCR were consistent with those obtained by sequencing, which confirmed the reliability of our sequencing results.

\section{Discussion}


270 In the present study, dynamical lncRNAs, mRNAs and miRNAs expression profiles in ovary 271 activation and oviposition processes in honey bees were identified. However, the complex

272 molecular mechanism behind the oviposition activation and regulation still needs to be illustrated.

273 Representative enriched pathways

274 The gene function analysis showed that DE RNAs enrichment was seen in a number of pathways

275 in ovary activation and/or oviposition regulation process. Some of the pathways are particularly 276 interesting, such as Wnt, hippo, TGF-beta, notch, MAPK, FoxO and mTOR signaling pathways 277 (Fig.3). More than 50\% of the genes in those pathways were differently expressed according to 278 our results. Some of the pathways have known or suspected roles in honey bees. For example, 279 Wnt, hippo, notch, MAPK and TOR pathways were reported to be involved in caste

280

281

282

283

284

285

286

287

288

289

290

291

292

293

294

295

determination in honey bees (Ashby et al. 2016; Wheeler et al. 2014). Caste determination is inseparably linked with the ovary development status. Although, so far, studies on the effect of these pathways on oviposition are not available, some insights can be drawn from other species.

The Wnt signaling pathway was found to be involved in the development of reproductive system such as the development of ovarian follicules, ovulation and luteinization (Sun \& Wang 2003). The hippo signaling pathway was also reported to be related to the regulation of mouse ovarian functional remodeling (Ye et al. 2017). Moreover, the hippo signaling pathway can coordinate with Wnt, TGF-beta and notch signaling pathways affecting organ size in Drosophila (Barry \& Camargo 2013). Because after queen mating, the size of ovary will become bigger than the virgin's (Rinderer 1987), we also observed many genes in Wnt, TGF-beta, hippo and notch signaling pathways that were differentially expressed in mated queens compared with virgin queens. It indicated that those pathways may participate in ovarian function remodeling after mating to prepare for oviposition in honey bees. The oocyte growth and development is crucial to successful oviposition, particularly during the height of the brood-rearing season when a good queen can lay up to 1, 500 eggs per day (Koeniger 2008). Studies in mammal found that TGFbeta, MAPK and FoxO signaling pathways regulate oocytes growth and development (Edmonds 
296

297

298

299

300

301

302

303

304

305

306

307

308

309

310

311

312

313

314

315

316

317

318

319

320

321

et al. 2010; Kretzschmar et al. 1997; Zhang et al. 2011). Also, there were studies showing that the TGF-beta signaling pathway was essential for oogenesis in Drosophila (Twombly et al. 1996). TGF-beta, MAPK and FoxO signaling pathways demonstrated enrichment in DE RNAs in our results, which indicated that these pathways may involve in oocyte growth and development in honey bees.

The queen is the only fertile female in a honey bee colony, and it constrains the reproduction of worker bees. A recent study reported that notch signaling facilitated the queen to repress ovary activity and maintain reproductive sterility in the worker bees (Duncan et al. 2016). Also, TOR pathway was found to be associated with the reproductive status in workers (Patel et al. 2007). DE RNAs enrichment was observed in the present study in both notch and TOR signaling pathways in mated queens which demonstrated that notch and TOR pathways possessed signaling functions in strengthening the reproductive constraint after queen mating.

Further, the studied pathway maps were looked up in KEGG database to assess whether there is a relationship among them. The results showed that they were closely interacting with each other as shown in Fig.3, whereby for example TGF-beta signaling pathway was part of hippo and Wnt signaling pathways. These pathways were enriched both in oviposition activation and oviposition process. Considering roles of these pathways in ovarian function remodeling, oocyte growth and development and other related processes, they are critical for a successful oviposition by complex fine-tuning relationships.

Among the DE genes in those pathways, several genes were found to participate in more than one pathway. The gene nejire (Nej, also known as CREB-binding protein $(C B P))$ participated in three pathways, namely notch, FoxO and TGF-beta signaling pathways. Additionally, Nej was significantly up-regulated in the egg-laying queens compared to virgin queens. Also studies in Drosophlia melanogaster found that Nej was involved in regulation of many pathways during embryo development, through hedgehog, wingless and TGF-beta signaling pathways (Fernandez-Nicolas \& Belles 2016). Taken together, we could conclude that Nej may participate 
322 in embryonic development in honey bees through notch, FoxO and TGF-beta signaling pathways,

323 and can be considered as the potential candidate genes for oviposition.

324 Genes and IncRNAs co-localized in QTL region for ovary size

325 We compared the location of the DE genes and DE lncRNAs on the honey bee genome available 326 at the NCBI database (Amel_4.5) with one QTL for ovary size. 73 genes and 14 lncRNAs were 327 identified, and some of them together with their key function will be explained further.

328 Among the 73 genes, G2/mitotic-specific cyclin-B3 $(C y c B 3)$ is the one we paid special attention.

329 It was shown for example that $C y c B 3$ controlled oocyte maturation and early embryo 330 development in mouse (Polański et al. 2012), but studies of CycB3 in reproduction in honey bees 331 are scarce. Fig.3 showed that $C y c B 3$ was significantly up-regulated in ovary activation process 332 and participated in the FoxO signaling pathway, which implies that $C y c B 3$ may play important 333 roles in oviposition and affect oocyte maturation in honey bees through FoxO signaling pathway.

334 Two lncRNAs, XLOC_073978 and XLOC_081294 (sequence information noted in 335 Supplemental Table S2) are of particular interest. The predicted targets of XLOC_073978 336 included myophilin-like, yellow-f and cytochrome P450 9Q1 (CYP9Q1). The predicted targets of 337 XLOC_081294 included yellow-b, odorant binding protein 10 (Obp10), myosin regulatory light 338 chain 2 (Mlc2), CYP9Q1, CYP9Q2 and CYP9Q3. Myophilin (also known as CHD64) was 339 previously identified as $J H$ response gens (Rewitz et al. 2006), which regulated many aspects of 340 physiology and development of insects (Flatt et al. 2005), including reproduction (Flatt et al. 341 2005; Goodman \& Cusson 2012; Hartfelder \& Emlen 2005; Riddiford 1994; Wyatt \& Davey 342 1996). Mlc2 was previously detected changing expression during the ovary activation process 343 (Manfredini et al. 2015). Concerning yellow-b, yellow-f and Obp10, they had been reported to 344 relate to ovary activation and response with $E c$, one of the most critical hormones affecting 345 reproduction in honey bees and other insects (Amdam et al. 2010; Bloch et al. 2000; Hagedorn 346 1985; Pandey \& Bloch 2015). Furthermore, it is notable that three target genes from CYP450 347 family (CYP9Q1,CYP9Q2 and $C Y P 9 Q 3)$, some of which were previously detected to interact 
348 with Ec (Mello et al. 2014; Rewitz et al. 2006), showed changes of expressions in our results.

349 Therefore, all the predicted targets of XLOC_073978 and XLOC_081294 were associated with 350 reproduction in honey bees. This highlights their roles in oviposition. Because the genes 351 elsewhere in the genome might share pathways with genes in the QTL region and reflect 352 downstream effects of the QTL (Fernandezrodriguez et al. 2011), they will be useful for 353 identifying candidate genes and/or RNAs for ovary activation and oviposition by combining the 354 information obtained from expression analysis with the QTL location analyses. Further studies 355 will involve in studying the genes that interacted with the QTL genes.

\section{Analysis of DE RNAs with known or suspected roles in reproduction}

357 Table 3 and Table 4 show that $31 \mathrm{mRNAs}$ and 36 miRNAs were significantly regulated in caste determination or other reproductive related process, which indicated that they have known or suspected roles of in ovary activation. The oviposition status is positively correlated with two genes (heat shock protein $90\left(H_{s p} 90\right)$ and $\left.U s p\right)$ and negatively correlated with ten genes. Hsp90 has been reported as a candidate marker gene for caste-specific ovary development (Lago et al. 2016). According to our results, $H s p 90$ can also be a candidate marker for the oviposition status of the honey bee queen. Among the negatively correlated genes, four are CYP450 family genes. Several genes of CYP450 family were reported to act as response genes of Ec and 20hydroxyecdysone (20E) which is the active Ec in most insects (Buszczak \& Segraves 1998) including honey bees (Yamazaki et al. 2011). Importantly, some CYP450 genes were identified as targets of lncRNAs, which are located in the QTL region of ovary size in our results. This highlights their roles in oviposition.

The other six miRNAs that are negatively correlated with the oviposition status are bantam, miR12, miR-279a-3p, miR-31a, miR-993 and miR-996. Bantam plays an important role in embryonic development and was identified as a crucial target of the signaling pathways of hippo and EGFR/MAPK in Drosophila (Herranz et al. 2012; Nolo et al. 2006; Thompson \& Cohen 2006). The DE mRNAs enrichment was seen in hippo and EGFR/MAPK signaling pathways in 
374

375

376

377

378

379

380

381

382

383

384

385

386

387

388

389

390

391

392

393

394

395

396

397

398

399

our study, suggesting that bantam may affect ovary activation or oviposition by the hippo and/or EGFR/MAPK signaling pathway. Also four miRNAs (miR-1, miR-133, miR-184 and miR-190) were down-regulated during oviposition activation and recovery, but the suspension of oviposition did not affect their expression. MiR-184, which is highly conserved and widely studied in insects, was reported to affect caste determination of honey bees (Guo et al. 2013; Macedo et al. 2016; Mello et al. 2014; Shi et al. 2015). Furthermore, studies in Dorsophlia found that loss of miRNA-184 induced loss of egg production (Iovino et al. 2009). In our trial, miRNA184 was down-regulated in mated queens but not in virgin queens. Thus, it can be speculated that miRNA-184 could be a candidate marker for oviposition of the honey bee queen.

In addition, a positive correlation was observed between a set of three miRNAs (miR-263a, miR2944-3p and miR-92b) and the oviposition status. MiR-263a and miR-92b were found to be involved in neuronal development and affected caste determination in honey bees (Ashby et al. 2016), which played important roles in reproductive activities (Heifetz et al. 2014). When queen's oviposition are activated or regulated, the neuronal activity and excitability increases. Therefore, we deduced that miR-263a, miR-2944-3p and miR-92b might be associated with the neuronal development and they further affect oviposition activation and regulation.

Furthermore, as shown in table 4, many miRNAs, which respond to $E c, J H$ and vitellogenin $(V g)$, showed significant changes in their expressions. $E c, V g$ and $J H$ are among the most important hormones in regulating reproductive activities in honey bees (Lago et al. 2016; Nunes et al. 2013; Oxley \& Oldroyd 2010). Particularly, Vg serves as a yolk precursor in egg development and affects oviposition in almost all oviparous species (Stephen M. Downs 2009). Changes of expressions of miRNAs in our study may regulate or be regulated by $E c, V g$ and $J H$, and further affect ovary activation and/or oviposition.

\section{Key roles in the IncRNA-miRNA-mRNA network}

In the network constructed with miRNAs, mRNAs and lncRNAs, we found that some genes served as bridges linking different miRNAs, four of which (gene id: 408284, 408609, 409587, 
400

401

402

403

404

405

406

407

408

409

410

411

412

413

414

415

416

417

418

419

420

421

422

423

424

425

and 409152) acting as miRNA targets linked let-7, miR-100, miR-12, miR-14, miR-316 and miR-996. Two of them are worthy of noting here. One was coiled-coil domain-containing protein 93 (CCDC93, id: 408609). Oh et al. (2011) found that CCDC93 regulated the expression level of cyclin B1 $(C y c B 1)$, a cyclin gene in human cells. Our results showed that $C y c B 3$, another cyclin gene, was localized in the QTL region for ovary size, which indicated that CCDC93 may interact with cyclin genes and further affect oviposition. The other was heat shock $70 \mathrm{kDa}$ protein cognate (Hsc70-3, id: 409587). The interaction between $H s c 70$ and $H s p 90$ was reported previously (King et al. 2001). More importantly, the Hsc70/Hsp90 chaperone machinery is responsible for loading small RNA duplexes into Argonaute proteins, which are critical to small silencing RNAs—-small interfering RNAs (siRNAs) or microRNAs (miRNAs) - direct posttranscriptional gene silencing of their mRNA targets (Iwasaki et al. 2010). Therefore, Hsc70 is essential for miRNAs to implement their impact on the expression of target mRNAs. Our results confirm similar findings showing that $H s c 70-3$ acted as a target of miRNA and served as a bridge linking different miRNAs in the lncRNA-miRNA-mRNA network, which highlight its role in the interaction among different RNAs in oviposition. Taken together, we can conclude that both $C C D C 93$ and $H s c 70-3$ play important roles in the network and further affect gene expressions in oviposition.

\section{Conclusions}

In the present study, lncRNAs, mRNAs and miRNAs expression profiles were evaluated and compared during ovary activation and dynamical oviposition process in honey bees. Bioinformatic analyses suggest that some lncRNAs, miRNA and genes are involved in important biological processes associated with oviposition activation and regulation. Additionally, lncRNA-miRNA-mRNA network revealed the potential interactions among different RNAs. Moreover, candidate genes or RNAs for oviposition were identified, which are particularly attractive for further in-depth studies.

\section{Acknowledgements}


426 The authors thank Wei Feng, who is the beekeeper in the apiary, for his assistance in beekeeping.

\section{Supplemental list}

428 Table S1 Information of real time PCR

429 Sheet1 Real time PCR validation result of selected lncRNAs, mRNAs and miRNAs

430 Sheet2 Primers for real time PCR

431 Table S2 List of DE lncRNA, mRNA and miRNA

432 Sheet1 DE lncRNAs and DE mRNAs in the ovary activation process

433 Sheet2 DE lncRNAs and DE mRNAs in oviposition inhibition process

434 Sheet3 DE lncRNAs and DE mRNAs in oviposition recovery process

435 Sheet 4 LncRNA chromosomal location and sequence information

436 Sheet5 DE miRNAs in ovary activation process

437 Sheet6 DE miRNAs in oviposition inhibition process

438 Sheet7 DE miRNAs in oviposition recovery process

439 Table S3 Functional annotation result of DE mRNAs

440 Sheet1 Enriched GO terms for DE mRNAs in ovary activation process

441 Sheet2 Enriched GO terms for DE mRNAs in oviposition inhibition process

442 Sheet3 Enriched GO terms for DE mRNAs in oviposition recovery process

443 Sheet4 Enriched KEGG pathways for DE mRNAs in ovary activation process

444 Sheet5 Enriched KEGG pathways for DE mRNAs in oviposition inhibition process

445 Sheet6 Enriched KEGG pathways for DE mRNAs in oviposition recovery process

446 Table S4 Functional annotation result of DE lncRNAs

447 Sheet1 Enriched GO terms for DE lncRNAs in ovary activation process

448 Sheet2 Enriched GO terms for DE lncRNAs in oviposition inhibition process

449 Sheet3 Enriched GO terms for DE lncRNAs in oviposition recovery process

450 Sheet4 Enriched KEGG pathways for DE lncRNAs in ovary activation process

451 Sheet5 Enriched KEGG pathways for DE lncRNAs in oviposition inhibition process

452 Sheet6 Enriched KEGG pathways for DE lncRNAs in oviposition recovery process 
453 Table S5 Functional annotation result of DE miRNAs

454 Sheet1 Enriched GO terms for DE miRNAs in ovary activation process

455 Sheet2 Enriched GO terms for DE miRNAs in oviposition inhibition process

456 Sheet3 Enriched GO terms for DE miRNAs in oviposition recovery process

457 Sheet4 Enriched KEGG pathways for DE miRNAs in ovary activation process

458 Sheet5 Enriched KEGG pathways for DE miRNAs in oviposition inhibition process

459 Sheet6 Enriched KEGG pathways for DE miRNAs in oviposition recovery process

460 Table S6 Genes and lncRNAs located in the QTL region for ovary size

461 Table S7 LncRNA-miRNA and miRNA-mRNA pairs to construct the network

462 Table S8 LncRNA-miRNA and miRNA-mRNA pairs with RNAs have known roles in

463 reproduction and/or RNAs located in the QTL region for ovary size

464 Figure S1 The lncRNA-miRNA-mRNA network with at least one DE RNA in a lncRNA465 miRNA pair or a miRNA-mRNA pair. 
466

467

468

469

470

471

472

473

474

475

476

477

478

479

480

481

482

483

484

485

486

487

488

489

490

491

492

493

494

495

496

497

498

499

500

501

502

503

504

505

\section{References}

Amdam GV, Page RE, Fondrk MK, and Brent CS. 2010. Hormone response to bidirectional selection on social behavior. Evolution \& development 12:428-436.

Ashby R, Forêt S, Searle I, and Maleszka R. 2016. MicroRNAs in Honey Bee Caste Determination. Sci Rep 6.

Barry ER, and Camargo FD. 2013. The Hippo superhighway: signaling crossroads converging on the Hippo/Yap pathway in stem cells and development. Curr Opin Cell Biol 25:247-253. 10.1016/j.ceb.2012.12.006

Bloch G, Hefetz A, and Hartfelder K. 2000. Ecdysteroid titer, ovary status, and dominance in adult worker and queen bumble bees (Bombus terrestris). Journal of Insect Physiology 46:1033-1040.

Boecking O, Bienefeld K, and Drescher W. 2000. Heritability of the Varroa-specific hygienic behaviour in honey bees (Hymenoptera : Apidae). Journal of Animal Breeding and Genetics-Zeitschrift Fur Tierzuchtung Und Zuchtungsbiologie 117:417-424. DOI 10.1046/j.1439-0388.2000.00271.x

Buszczak M, and Segraves WA. 1998. Drosophila metamorphosis: The only way is USP?: Current Biology. Current Biology 8:879-882.

Duncan EJ, Hyink O, and Dearden PK. 2016. Notch signalling mediates reproductive constraint in the adult worker honeybee. Nature Communications 7.

Edmonds JW, Prasain JK, Dorand D, Yang Y, Hoang HD, Vibbert J, Kubagawa HM, and Miller MA. 2010. Insulin/FOXO signaling regulates ovarian prostaglandins critical for reproduction. Developmental Cell 19:858-871.

Enright AJ, John B, Gaul U, Tuschl T, Sander C, and Marks DS. 2003. MicroRNA targets in Drosophila. Genome Biol 5:: R1.

Fan C, Hao Z, Yan J, and Li G. 2015. Genome-wide identification and functional analysis of lincRNAs acting as miRNA targets or decoys in maize. BMC Genomics 16:1-19.

Fernandez-Nicolas A, and Belles X. 2016. CREB-binding protein contributes to the regulation of endocrine and developmental pathways in insect hemimetabolan pre-metamorphosis. Biochim Biophys Acta 1860:508.

Fernandezrodriguez A, Munoz M, Fernandez A, Pena RN, Tomas A, Noguera JL, Ovilo C, and Fernandez AI. 2011. Differential Gene Expression in Ovaries of Pregnant Pigs with High and Low Prolificacy Levels and Identification of Candidate Genes for Litter Size1. Biol Reprod 84:299-307.

Flatt T, Tu MP, and Tatar M. 2005. Hormonal pleiotropy and the juvenile hormone regulation of Drosophila development and life history. Bioessays 27:999-1010.

Friedländer MR, Mackowiak SD, Li N, Chen W, and Rajewsky N. 2012. miRDeep2 accurately identifies known and hundreds of novel microRNA genes in seven animal clades. Nucleic Acids Res 40:37-52.

Gary N. 1992. The Hive and the Honey bee. In: Graham JM, ed. The Hive and the Honey bee: Dadant \& Sons, Inc, 271-307.

Gong Z, Qian Y, Zeng Z, Zhang W, Li X, Zu X, Hao D, Pan C, Liao Q, and Bo X. 2016. An integrative transcriptomic analysis reveals p53 regulated miRNA, mRNA, and lncRNA networks in nasopharyngeal carcinoma. Tumor Biology 37:1-13.

Goodman WG, and Cusson M. 2012. 8-The Juvenile Hormones: Plenum Press.

Graham AM, Munday MD, Kaftanoglu O, Page RE, Amdam GV, and Rueppell O. 2011. Support for the reproductive ground plan hypothesis of social evolution and major QTL for ovary traits of Africanized worker honey bees (Apis mellifera L.). BMC Evol Biol 11:95. 
506

507

508

509

510

511

512

513

514

515

516

517

518

519

520

521

522

523

524

525

526

527

528

529

530

531

532

533

534

535

536

537

538

539

540

541

542

543

544

545

546

Griffiths-Jones S. 2010. miRBase: microRNA sequences and annotation. Curr Protoc Bioinformatics Chapter 12:Unit 1219 11-10. 10.1002/0471250953.bi1209s29

Guo X, Su S, Skogerboe G, Dai S, Li W, Li Z, Liu F, Ni R, Guo Y, and Chen S. 2013. Recipe for a busy bee: microRNAs in Honey Bee caste determination. PLoS One 8:e81661.

Hagedorn HH. 1985. 7 - The Role of Ecdysteroids in Reproduction. Endocrinology II:205-262.

Harbo JR. 1986. Propagation and Instrumental Insemination - Bee Genetics and Breeding - CHAPTER 15. Bee Genetics \& Breeding 01:361-389.

Hartfelder K, and Emlen DJ. 2005. 3.13-Endocrine Control of Insect Polyphenism. Comprehensive Molecular Insect Science:651-703.

Heifetz Y, Lindner M, Garini Y, and Wolfner M. 2014. Mating Regulates Neuromodulator Ensembles at Nerve Termini Innervating the Drosophila Reproductive Tract. Current Biology Cb 24:731-737.

Herranz H, Hong X, and Cohen S. 2012. Mutual Repression by Bantam miRNA and Capicua Links the EGFR/MAPK and Hippo Pathways in Growth Control. Current Biology Cb 22:651-657.

Hoover SER, Keeling CI, Winston ML, and Slessor KN. 2003. The effect of queen pheromones on worker honey bee ovary development. Naturwissenschaften 90:477-480.

Humann FC, and Hartfelder K. 2011. Representational Difference Analysis (RDA) reveals differential expression of conserved as well as novel genes during caste-specific development of the honey bee ( Apis mellifera L.) ovary. Insect Biochemistry \& Molecular Biology 41:602-612.

Iovino N, Pane A, and Gaul U. 2009. miR-184 has multiple roles in Drosophila female germline development. Dev Cell 17:123-133. 10.1016/j.devcel.2009.06.008

Iwasaki S, Kobayashi M, Yoda M, Sakaguchi Y, Katsuma S, Suzuki T, and Tomari Y. 2010. Hsc70/Hsp90 Chaperone Machinery Mediates ATP-Dependent RISC Loading of Small RNA Duplexes. Mol Cell 39:292.

Jayakodi M, Jung JW, Park D, Ahn YJ, Lee SC, Shin SY, Shin C, Yang TJ, and Kwon HW. 2015. Genome-wide characterization of long intergenic non-coding RNAs (lincRNAs) provides new insight into viral diseases in honey bees Apis cerana and Apis mellifera. BMC Genomics 16:680. 10.1186/s12864-015-1868-7

King FW, Wawrzynow A, Höhfeld J, and Zylicz M. 2001. Co-chaperones Bag-1, Hop and Hsp40 regulate Hsc70 and Hsp90 interactions with wild-type or mutant p53. Embo Journal 20:6297-6305.

Koeniger G. 2008. Bee Genetics and Breeding. In: Rinderer TE, ed. Bee Genetics \& Breeding: Academic Press (London), 255-275.

Kramarenko AS, Lopukchov AA, Gladyr EA, Singina GN, Ermilov AN, Yanchukov IN, Brem G, and Zinovieva NA. 2014. 206 genome-wide associations for reproductive traits in Russian holstein population. Reproduction Fertility \& Development 27:194.

Kretzschmar M, Doody J, and Massagué J. 1997. Opposing BMP and EGF signalling pathways converge on the TGF-beta family mediator Smad1. Nature 389:618-622.

Lago DC, Humann FC, Barchuk AR, Abraham KJ, and Hartfelder K. 2016. Differential gene expression underlying ovarian phenotype determination in honey bee, Apis mellifera L, caste development. Insect Biochemistry \& Molecular Biology 79:1-12.

Langmead B, Trapnell C, Pop M, Salzberg SL, and Quals P. 2009. Ultrafast and memory-efficient alignment of short reads to the human genome. 10.

Linksvayer TA, Rueppell O, Siegel A, Kaftanoglu O, Jr PR, and Amdam GV. 2009. The genetic basis of transgressive ovary size in honeybee workers. Genetics 183:693.

Peer] reviewing PDF | (2017:02:16330:3:0:NEW 30 Aug 2017) 
547

548

549

550

551

552

553

554

555

556

557

558

559

560

561

562

563

564

565

566

567

568

569

570

571

572

573

574

575

576

577

578

579

580

581

582

583

584

585

586

587

Macedo LMF, Nunes FMF, Freitas FCP, Pires CV, Tanaka ED, Martins JR, Piulachs MD, Cristino AS, Pinheiro DG, and Simões ZLP. 2016. MicroRNA signatures characterizing caste-independent ovarian activity in queen and worker honeybees ( A pis mellifera L.). Insect Mol Biol 25:216-226.

Manfredini F, Brown MJF, Vergoz V, and Oldroyd BP. 2015. RNA-sequencing elucidates the regulation of behavioural transitions associated with the mating process in honey bee queens. BMC Genomics 16:563.

Mao X, Cai T, Olyarchuk JG, and Wei L. 2005. Automated genome annotation and pathway identification using the KEGG Orthology (KO) as a controlled vocabulary. Bioinformatics 21:3787-3793. 10.1093/bioinformatics/bti430

Mello TRP, Aleixo AC, Pinheiro DG, Nunes FMF, Bitondi MMG, Hartfelder K, Barchuk AR, and Simões ZLP. 2014. Developmental regulation of ecdysone receptor $(\mathrm{EcR})$ and EcR-controlled gene expression during pharate-adult development of honeybees (Apis mellifera). Front Genet 5:445.

Ming W, Yang S, Shi S, and Tian T. 2012. miREvo: an integrative microRNA evolutionary analysis platform for next-generation sequencing experiments. Bmc Bioinformatics 13:1-10.

Necsulea A, Soumillon M, Warnefors M, Liechti A, Daish T, Zeller U, Baker JC, Grützner F, and Kaessmann H. 2014. The evolution of lncRNA repertoires and expression patterns in tetrapods. Nature 505:635-640.

Nolo, Riitta, Morrison, Clayton M, Tao, Chunyao, Zhang, Xinwei, Halder, and Georg. 2006. The bantam MicroRNA Is a Target of the Hippo Tumor-Suppressor Pathway. Current Biology 16:1895-1904.

Nunes FM, Ihle KE, Mutti NS, Simões ZL, and Amdam GV. 2013. The gene vitellogenin affects microRNA regulation in honey bee (Apis mellifera) fat body and brain. Journal of Experimental Biology 216:3724.

Oh YJ, Lee EH, Lee IK, Kim K-S, and Kim H. 2011. Coiled-Coil Domain-Containing Protein 98 (CCDC98) Regulates Cyclin B1 Expression by Affecting WTAP Protein Stability. Journal of Life Science 21:10671075.

Okazaki Y, Furuno M, Kasukawa T, Adachi J, Bono H, Kondo S, Nikaido I, Osato N, Saito R, and Suzuki H. 2002. Analysis of the mouse transcriptome based on functional annotation of 60,770 full-length cDNAs. Nature 420:563-573.

Ota T, Suzuki Y, Nishikawa T, Otsuki T, Sugiyama T, Irie R, Wakamatsu A, Hayashi K, Sato H, and Nagai K. 2004. Complete sequencing and characterization of 21,243 full-length human cDNAs. Nature Genetics 36:40-45.

Oxley PR, and Oldroyd BP. 2010. Chapter 3 - The Genetic Architecture of Honeybee Breeding: Elsevier Science \& Technology.

Pandey A, and Bloch G. 2015. Juvenile hormone and ecdysteroids as major regulators of brain and behavior in bees. Current Opinion in Insect Science 12:26-37.

Patel A, Fondrk MK, Kaftanoglu O, Emore C, Hunt G, Frederick K, and Amdam GV. 2007. The making of a queen: TOR pathway is a key player in diphenic caste development. PLoS One 2:e509. 10.1371/journal.pone.0000509

Polański Z, Homer HA, and Kubiak JZ. 2012. Cyclin B in mouse oocytes and embryos: importance for human reproduction and aneuploidy. Results \& Problems in Cell Differentiation 55:69.

Rewitz KF, Rybczynski RWarren JT, and Gilbert LI. 2006. Developmental expression of Manduca shade, the P450 mediating the final step in molting hormone synthesis. Molecular \& Cellular Endocrinology 247:166-174.

Riddiford LM. 1994. Cellular and Molecular Actions of Juvenile Hormone I. General Considerations and Premetamorphic Actions. Advances in Insect Physiology 24:213-274.

Rinderer TE. 1987. Bee genetics and breeding. The Quarterly Review of Biology. 
Schneider SS. 1992. The Hive and the Honey bee. In: Graham JM, ed. The Hive and the Honey bee: Dadant \& Sons, Inc, 73-100.

Shi YY, Zheng HJ, Pan QZ, Wang ZL, and Zeng ZJ. 2015. Differentially expressed microRNAs between queen and worker larvae of the honey bee ( Apis mellifera ). Apidologie 46:35-45.

Smoot ME, Ono K, Ruscheinski J, Wang PL, and Ideker T. 2011. Cytoscape 2.8: new features for data integration and network visualization. Bioinformatics 27:431-432. 10.1093/bioinformatics/btq675

Spötter A, Gupta P, Nurnberg G, Reinsch N, and Bienefeld K. 2012. Development of a 44K SNP assay focussing on the analysis of a varroa-specific defence behaviour in honey bees (Apis mellifera carnica). Molecular Ecology Resources 12:323-332. 10.1111/j.1755-0998.2011.03106.x

Stephen M. Downs JO, John Klinger. 2009. Fatty acid oxidation and meiotic resumption in mouse oocytes. Molecular Reproduction \& Development 76:844-853.

Sun X, and Wang Y. 2003. Wnt signaling pathways in mammalian reproduction. Progress in Biochemistry \& Biophysics 30:180-184.

Thompson BJ, and Cohen SM. 2006. The Hippo pathway regulates the bantam microRNA to control cell proliferation and apoptosis in Drosophila. Cell 126:767-774.

Wheeler DE, Buck NA, and Evans JD. 2014. Expression of insulin/insulin-like signalling and TOR pathway genes in honey bee caste determination. Insect Mol Biol 23:113-121. 10.1111/imb.12065

Wilusz JE, Sunwoo H, and Spector DL. 2009. Long noncoding RNAs: functional surprises from the RNA world. Genes Dev 23:1494-1504. 10.1101/gad.1800909

Woodward DR. 2010. Queen bee : biology, rearing and breeding: Northern Bee Books.

Wyatt GR, and Davey KG. 1996. Cellular and Molecular Actions of Juvenile Hormone. II. Roles of Juvenile Hormone in Adult Insects. Advances in Insect Physiology 26:1-155.

Yamazaki Y, Kiuchi M, Takeuchi H, and Kubo T. 2011. Ecdysteroid biosynthesis in workers of the European honeybee Apis mellifera L. Insect Biochemistry \& Molecular Biology 41:283-293.

Ye H, Li X, Zheng T, Hu C, Pan Z, Huang J, Li J, Li W, and Zheng Y. 2017. The Hippo Signaling Pathway Regulates Ovarian Function via the Proliferation of Ovarian Germline Stem Cells. Cellular Physiology \& Biochemistry International Journal of Experimental Cellular Physiology Biochemistry \& Pharmacology 41:1051.

Young MD, Wakefield MJ, Smyth GK, and Oshlack A. 2012. goseq: Gene Ontology testing for RNA-seq datasets.

Zhang DX, Park WJ, Sun SC, Xu YN, Li YH, Cui XS, and Kim NH. 2011. Regulation of maternal gene expression by MEK/MAPK and MPF signaling in porcine oocytes during in vitro meiotic maturation. Journal of Reproduction \& Development 57:49. 


\section{Figure 1 (on next page)}

The cluster heat map of expression profiles of IncRNAs, mRNAs and miRNAs at different status during ovary activation and oviposition regulation.

A. The cluster heat map of expression profiles of IncRNAs; B. The cluster heat map of expression profiles of mRNAs; C. The cluster heat map of expression profiles of miRNAs.

$V$, group of virgin queens $(n=3) ; Q$, group of egg-laying queens $(n=3) ; C$, group of egg-laying inhibited queens $(n=3) ; R$, group of egg-laying recovery queens $(n=3)$. 
Figure 2 (on next page)

The reproductive associated IncRNA-miRNA-mRNA network.

The network was constructed with DE IncRNAs, DE miRNAs and DE mRNAs which have known or suspected roles in reproduction and/or located in the QTL region for ovary size. Purple square nodes represent IncRNAs. Red triangle nodes represent miRNAs. Blue circle nodes represent mRNAs. 


$$
\text { GNAI1 SUR }
$$

\section{SUR}

\section{ZNT1}

IMPL2

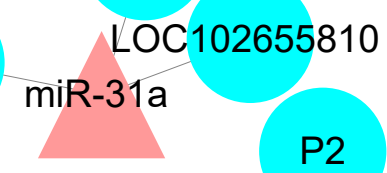

$$
\text { miR-31a }
$$

LOC 102655810

2

\section{to be reviewed}

PKC1

LOC725681
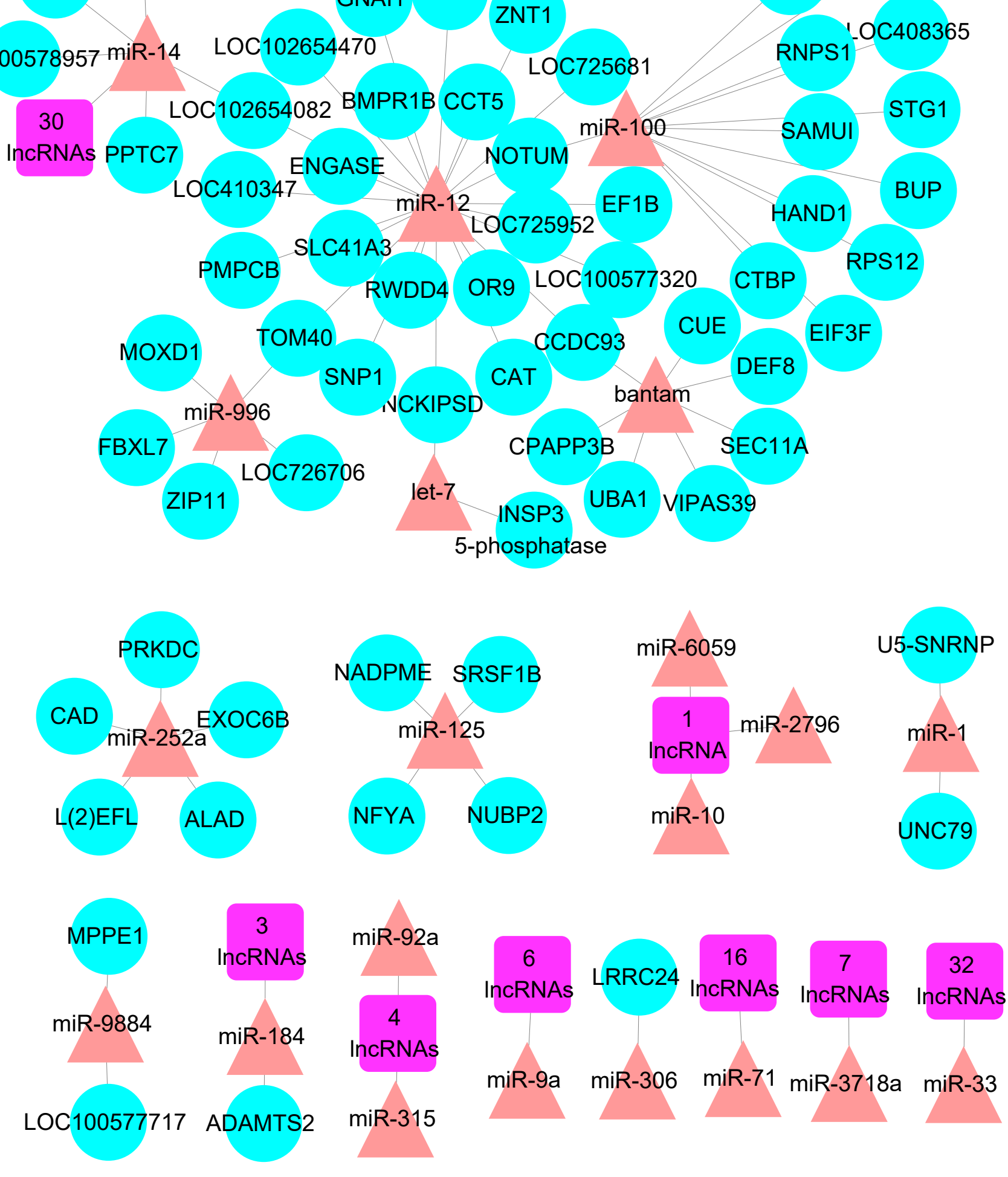


\section{Figure 3 (on next page)}

The representative enriched pathways map.

DE genes were marked with blue color. Genes without color and “......" stand for genes that involved in the pathway but not differentially expressed in our results. 


\section{Table $\mathbf{1}$ (on next page)}

Number of differentially expressed coding and non-coding RNAs identified from each comparison. 


\begin{tabular}{|c|c|c|c|c|c|c|}
\hline \multirow[t]{2}{*}{$\begin{array}{l}\text { Number of differentially } \\
\text { expressed RNAs }\end{array}$} & \multicolumn{2}{|l|}{$\begin{array}{l}\text { (Egg-laying } \\
\text { virgin queens) }\end{array}$} & \multicolumn{2}{|c|}{$\begin{array}{l}\text { Oviposition inhibition } \\
\text { (Egg-laying inhibited queens compared with } \\
\text { egg-laying queens) }\end{array}$} & \multicolumn{2}{|c|}{$\begin{array}{l}\qquad \text { Oviposition recovery } \\
\text { (Egg-laying recovery queens compared with egg- } \\
\text { laying inhibited queens) }\end{array}$} \\
\hline & Up-regulated & Down-regulated & Up-regulated & Down-regulated & Up-regulated & Down-regulated \\
\hline mRNAs & 3218 & 2263 & 266 & 72 & 256 & 241 \\
\hline lncRNAs & 224 & 516 & 57 & 31 & 40 & 60 \\
\hline miRNAs & 39 & 42 & 9 & 4 & 2 & 2 \\
\hline
\end{tabular}




\section{Table 2 (on next page)}

Intersection set of significantly enriched pathways with DE IncRNAs, DE mRNAs and DE miRNAs.

Note: V, group of virgin queens; Q, group of egg-laying queens; C, group of egg-laying inhibited queens; $R$, group of egg-laying recovery queens. 


\begin{tabular}{|c|c|c|c|c|c|c|c|}
\hline Significantly enriched pathways & Q_V & C_Q & $\mathrm{R} \_\mathrm{C}$ & Significantly enriched pathways & Q_V & C_Q & R_C \\
\hline Arginine and proline metabolism & & $\sqrt{ }$ & $\sqrt{ }$ & mTOR signaling pathway & $\sqrt{ }$ & $\sqrt{ }$ & $\sqrt{ }$ \\
\hline Base excision repair & $\sqrt{ }$ & & $\sqrt{ }$ & Mucin type O-Glycan biosynthesis & $\sqrt{ }$ & & \\
\hline Biosynthesis of amino acids & $\sqrt{ }$ & $\sqrt{ }$ & & Neuroactive ligand-receptor interaction & $\sqrt{ }$ & $\sqrt{ }$ & $\sqrt{ }$ \\
\hline Circadian rhythm - fly & $\sqrt{ }$ & $\sqrt{ }$ & $\sqrt{ }$ & N-Glycan biosynthesis & $\sqrt{ }$ & $\sqrt{ }$ & \\
\hline Cysteine and methionine metabolism & $\sqrt{ }$ & $\sqrt{ }$ & & Nitrogen metabolism & $\sqrt{ }$ & $\sqrt{ }$ & \\
\hline Dorso-ventral axis formation & $\sqrt{ }$ & $\sqrt{ }$ & $\sqrt{ }$ & Notch signaling pathway & $\sqrt{ }$ & $\sqrt{ }$ & $\sqrt{ }$ \\
\hline Drug metabolism - other enzymes & $\sqrt{ }$ & $\sqrt{ }$ & & Other glycan degradation & & & \\
\hline ECM-receptor interaction & $\sqrt{ }$ & $\sqrt{ }$ & & Peroxisome & $\sqrt{ }$ & & \\
\hline Endocytosis & $\sqrt{ }$ & $\sqrt{ }$ & & Phenylalanine metabolism & $\sqrt{ }$ & $\sqrt{ }$ & \\
\hline Folate biosynthesis & & $\sqrt{ }$ & & Phosphatidylinositol signaling system & $\sqrt{ }$ & $\sqrt{ }$ & $\sqrt{ }$ \\
\hline FoxO signaling pathway & $\sqrt{ }$ & $\sqrt{ }$ & $\sqrt{ }$ & Phototransduction - fly & $\sqrt{ }$ & $\sqrt{ }$ & $\sqrt{ }$ \\
\hline Galactose metabolism & $\sqrt{ }$ & & & Proteasome & $\sqrt{ }$ & $\sqrt{ }$ & \\
\hline Glycerolipid metabolism & $\sqrt{ }$ & $\sqrt{ }$ & $\sqrt{ }$ & Protein processing in endoplasmic reticulum & & $\sqrt{ }$ & \\
\hline Glycerophospholipid metabolism & $\sqrt{ }$ & $\sqrt{ }$ & $\sqrt{ }$ & Purine metabolism & $\sqrt{ }$ & $\sqrt{ }$ & $\sqrt{ }$ \\
\hline Glycosaminoglycan biosynthesis - chondroitin sulfate / dermatan sulfate & & $\sqrt{ }$ & & Retinol metabolism & & $\sqrt{ }$ & \\
\hline Glycosaminoglycan biosynthesis - heparan sulfate / heparin & & $\sqrt{ }$ & $\sqrt{ }$ & RNA degradation & $\sqrt{ }$ & $\sqrt{ }$ & $\sqrt{ }$ \\
\hline Hedgehog signaling pathway & $\sqrt{ }$ & $\sqrt{ }$ & & RNA transport & $\sqrt{ }$ & $\sqrt{ }$ & $\sqrt{ }$ \\
\hline Hippo signaling pathway - fly & $\sqrt{ }$ & $\sqrt{ }$ & $\sqrt{ }$ & Spliceosome & $\sqrt{ }$ & $\sqrt{ }$ & $\sqrt{ }$ \\
\hline Inositol phosphate metabolism & $\sqrt{ }$ & $\sqrt{ }$ & $\sqrt{ }$ & Starch and sucrose metabolism & $\sqrt{ }$ & & \\
\hline Jak-STAT signaling pathway & & & $\sqrt{ }$ & Sulfur metabolism & $\sqrt{ }$ & & \\
\hline Lysine degradation & $\sqrt{ }$ & & & TGF-beta signaling pathway & $\sqrt{ }$ & $\sqrt{ }$ & $\sqrt{ }$ \\
\hline MAPK signaling pathway - fly & $\sqrt{ }$ & $\sqrt{ }$ & $\sqrt{ }$ & Tyrosine metabolism & $\sqrt{ }$ & $\sqrt{ }$ & \\
\hline Metabolic pathways & $\sqrt{ }$ & $\sqrt{ }$ & $\sqrt{ }$ & Ubiquinone and other terpenoid-quinone biosynthesis & $\sqrt{ }$ & $\sqrt{ }$ & \\
\hline mRNA surveillance pathway & $\sqrt{ }$ & $\sqrt{ }$ & $\sqrt{ }$ & Wnt signaling pathway & $\sqrt{ }$ & $\sqrt{ }$ & $\sqrt{ }$ \\
\hline
\end{tabular}




\section{Table 3(on next page)}

Analysis of DE genes with known or suspected roles in honey bee reproduction or related process.

$V$, group of virgin queens ( $n=3)$; , group of egg-laying queens ( $n=3) ; C$, group of egg-laying inhibited queens $(n=3) ; R$, group of egg-laying recovery queens $(n=3)$. 


\begin{tabular}{|c|c|c|c|c|c|c|}
\hline \multirow[t]{2}{*}{ Gene id } & \multirow[t]{2}{*}{ Gene name } & \multirow[t]{2}{*}{ Correlate } & \multirow[t]{2}{*}{ Ref. } & \multicolumn{3}{|c|}{ Expression level in this study } \\
\hline & & & & Q vs. V & C vs. Q & $\mathrm{R} v s . \mathrm{C}$ \\
\hline 408961 & $\begin{array}{l}\text { Apolipophorins (known as } \\
R F A B P \text { ) }\end{array}$ & $J H$ response genes & $\begin{array}{l}\text { (Pandey \& } \\
\text { Bloch 2015) }\end{array}$ & Down-regulated & Up-regulated & Down-regulated \\
\hline 552515 & $\begin{array}{l}\text { ATP-dependent RNA helicase } \\
\text { WM6 (known as Helicase at 25E) }\end{array}$ & $\begin{array}{l}\text { Higher expressed in ovaries of queen } \\
\text { larvae compared with worker larvae in } \\
\text { fourth and early fifth larvae }\end{array}$ & $\begin{array}{l}\text { (Lago et al. } \\
2016)\end{array}$ & Up-regulated & $\begin{array}{l}\text { Down-regulated but } \\
\text { not significantly }\end{array}$ & $\begin{array}{l}\text { Up-regulated but } \\
\text { not significantly }\end{array}$ \\
\hline 408827 & Carbonic anhydrase $1(\mathrm{CAHI})$ & $J H$ response genes & $\begin{array}{l}\text { (Pandey \& } \\
\text { Bloch 2015) }\end{array}$ & Down-regulated & $\begin{array}{l}\text { Up-regulated but } \\
\text { not significantly }\end{array}$ & $\begin{array}{l}\text { Down-regulated but } \\
\text { not significantly }\end{array}$ \\
\hline 413762 & $\begin{array}{l}\text { Complement component } 1 \mathrm{Q} \\
\text { subcomponent-binding protein, } \\
\text { mitochondrial }\end{array}$ & $\begin{array}{l}\text { Higher expressed in ovaries of queen } \\
\text { larvae compared with worker larvae in } \\
\text { fourth and early fifth larvae }\end{array}$ & $\begin{array}{l}\text { (Lago et al. } \\
2016 \text { ) }\end{array}$ & Down-regulated & $\begin{array}{l}\text { Down-regulated but } \\
\text { not significantly }\end{array}$ & Up-regulated \\
\hline 726690 & $\begin{array}{lll}\begin{array}{l}\text { Cytochrome } \\
(C Y P 6 A S 3)\end{array} & \text { P450 } & 6 \text { AS3 } \\
\end{array}$ & $\begin{array}{l}\text { Up-regulated in the } E c R \text { knock down } \\
\text { bees }\end{array}$ & $\begin{array}{l}\text { (Mello et al. } \\
\text { 2014) }\end{array}$ & Down-regulated & Up-regulated & $\begin{array}{l}\text { Down-regulated but } \\
\text { not significantly }\end{array}$ \\
\hline 412209 & $\begin{array}{lll}\text { Cytochrome } & \text { P450 } & 6 \text { AS4 } \\
(\text { CYP6AS4) } & & \\
\end{array}$ & $\begin{array}{l}\text { Up-regulated in the } E c R \text { knock down } \\
\text { bees }\end{array}$ & $\begin{array}{l}\text { (Mello et al. } \\
\text { 2014) }\end{array}$ & Down-regulated & Up-regulated & Down-regulated \\
\hline 409677 & $\begin{array}{lll}\text { Cytochrome } & \text { P450 } & 6 \text { AS5 } \\
(\text { CYP6AS5) } & & \\
\end{array}$ & $\begin{array}{l}\text { Up-regulated in the } E c R \text { knock down } \\
\text { bees }\end{array}$ & $\begin{array}{l}\text { (Mello et al. } \\
\text { 2014) }\end{array}$ & Down-regulated & Up-regulated & Down-regulated \\
\hline 551560 & $\begin{array}{lll}\text { Cytochrome } & \text { P450 } & 6 \mathrm{BD} 1 \\
(\mathrm{CYP} 6 \mathrm{BD} 1) & & \\
\end{array}$ & $\begin{array}{l}\text { Up-regulated in the } E c R \text { knock down } \\
\text { bees }\end{array}$ & $\begin{array}{l}\text { (Mello et al. } \\
\text { 2014) }\end{array}$ & Down-regulated & Up-regulated & Down-regulated \\
\hline 411057 & $\begin{array}{llll}\begin{array}{l}\text { Cytochrome } \\
(\text { PYP314A1) }\end{array} & & 314 & \mathrm{~A} 1 \\
(\text { CYP } & & \\
\end{array}$ & coded for Ecdysone 20-hydroxylase & $\begin{array}{l}\text { (Rewitz et } \\
\text { al. 2006) }\end{array}$ & Up-regulated & No change & $\begin{array}{l}\text { Down-regulated but } \\
\text { not significantly }\end{array}$ \\
\hline 406143 & Defensin $1($ Defl $)$ & $\begin{array}{l}\text { Up-regulated in mated queens compared } \\
\text { with virgin queens }\end{array}$ & $\begin{array}{l}\text { (Manfredini } \\
\text { et al. 2015) }\end{array}$ & Down-regulated & Up-regulated & Down-regulated \\
\hline 406070 & Dopamine receptor 2 (Dopr2) & $E c$ response genes & $\begin{array}{l}\text { (Rewitz et } \\
\text { al. 2006) }\end{array}$ & Down-regulated & No change & Up-regulated \\
\hline 410309 & $\begin{array}{ll}\text { Ecdysone-induced protein } 75 \\
(E 75)\end{array}$ & $E c$ response genes & $\begin{array}{l}\text { (Rewitz et } \\
\text { al. 2006) }\end{array}$ & Up-regulated & $\begin{array}{l}\text { Up-regulated but } \\
\text { not significantly }\end{array}$ & No change \\
\hline 406084 & $E c$ dysone receptor $(E c R)$ & $E c$ response genes & (Rewitz et & Up-regulated & Not detected & Not detected \\
\hline
\end{tabular}




\begin{tabular}{|c|c|c|c|c|c|c|}
\hline & & & al. 2006) & & & \\
\hline 408758 & $\begin{array}{l}\text { Ecdysteroid-regulated gene E74 } \\
(E 74)\end{array}$ & $E c$ response genes & $\begin{array}{l}\text { (Rewitz et } \\
\text { al. 2006) }\end{array}$ & Up-regulated & No change & No change \\
\hline 409384 & Heat shock protein $60(H s p 60)$ & $\begin{array}{l}\text { Higher expressed in ovaries of queen } \\
\text { larvae compared with worker larvae in } \\
\text { fourth and early fifth larvae }\end{array}$ & $\begin{array}{l}\text { (Lago et al. } \\
2016)\end{array}$ & $\begin{array}{l}\text { Up-regulated } \\
\text { but not } \\
\text { significantly }\end{array}$ & Down-regulated & Up-regulated \\
\hline 408928 & Heat shock protein $90(H s p 90)$ & $\begin{array}{l}\text { Higher expressed in ovaries of queen } \\
\text { larvae compared with worker larvae in } \\
\text { fourth and early fifth larvae; candidate } \\
\text { marker genes for caste-specific ovary } \\
\text { development; }\end{array}$ & $\begin{array}{l}\text { (Lago et al. } \\
2016 \text { ) }\end{array}$ & Up-regulated & Down-regulated & Up-regulated \\
\hline 408818 & Hexokinase $(H K)$ & $Q M P$ response genes & $\begin{array}{l}\text { (Hoover et } \\
\text { al. 2003) }\end{array}$ & Up-regulated & No change & $\begin{array}{l}\text { Down-regulated but } \\
\text { not significantly }\end{array}$ \\
\hline 406117 & Hexamerin $70 \mathrm{~b}(\mathrm{Hex} 70 b)$ & $\begin{array}{l}J H \text { response gene, highly expressed in } \\
\text { fourth and early fifth-instar queen } \\
\text { ovaries }\end{array}$ & $\begin{array}{l}\text { (Lago et al. } \\
2016)\end{array}$ & Up-regulated & $\begin{array}{l}\text { Up-regulated but } \\
\text { not significantly }\end{array}$ & $\begin{array}{l}\text { Down-regulated but } \\
\text { not significantly }\end{array}$ \\
\hline 726542 & Histone $\mathrm{H} 3$ & $\begin{array}{l}Q M P \text { response genes; overrepresented in } \\
\text { ovaries of queens in the fifth larval instar }\end{array}$ & $\begin{array}{l}\text { (Humann \& } \\
\text { Hartfelder } \\
\text { 2011) }\end{array}$ & Down-regulated & No change & $\begin{array}{l}\text { Down-regulated } \\
\text { but not significantly }\end{array}$ \\
\hline 102655073 & Histone H4 & $Q M P$ response genes & $\begin{array}{l}\text { (Hoover et } \\
\text { al. 2003) }\end{array}$ & Up-regulated & $\begin{array}{l}\text { Up-regulated but } \\
\text { not significantly }\end{array}$ & $\begin{array}{l}\text { Down-regulated but } \\
\text { not significantly }\end{array}$ \\
\hline 726965 & $J H$-inducible protein & $\begin{array}{l}J H \text { and } E c \text { response gene, up-regulated in } \\
E c \text { knock down bess }\end{array}$ & $\begin{array}{l}\text { (Mello et al. } \\
\text { 2014) }\end{array}$ & Up-regulated & $\begin{array}{l}\text { Down-regulated but } \\
\text { not significantly }\end{array}$ & No change \\
\hline 100576395 & Kruppel homolog $1(K r-h l)$ & $\begin{array}{l}\text { an immediate response gene in the } J H \\
\text { response cascade }\end{array}$ & $\begin{array}{l}\text { (Lago et al. } \\
2016)\end{array}$ & Up-regulated & $\begin{array}{l}\text { Down-regulated but } \\
\text { not significantly }\end{array}$ & $\begin{array}{l}\text { Up-regulated but } \\
\text { not significantly }\end{array}$ \\
\hline 406121 & $\begin{array}{l}\text { Major royal jelly protein } 3 \\
\text { (Mrjp3) }\end{array}$ & $\begin{array}{l}E c \text { response gene; down-regulated in } E c \\
\text { knock down bees }\end{array}$ & $\begin{array}{l}\text { (Mello et al. } \\
\text { 2014) }\end{array}$ & Down-regulated & $\begin{array}{l}\text { Up-regulated but } \\
\text { not significantly }\end{array}$ & $\begin{array}{l}\text { Down-regulated but } \\
\text { not significantly }\end{array}$ \\
\hline 409870 & $\begin{array}{l}\text { Minor histocompatibility antigen } \\
\text { H13 }\end{array}$ & $\begin{array}{l}\text { Higher expressed in ovaries of queen } \\
\text { larvae compared with worker larvae in }\end{array}$ & $\begin{array}{l}\text { (Lago et al. } \\
\text { 2016) }\end{array}$ & Up-regulated & $\begin{array}{l}\text { Down-regulated but } \\
\text { not significantly }\end{array}$ & No change \\
\hline
\end{tabular}




\begin{tabular}{|c|c|c|c|c|c|c|}
\hline & & fourth and early fifth larvae & & & & \\
\hline 411820 & $\begin{array}{l}\text { Mitogen-activated protein kinase } \\
\text { phosphatase-3 (Mapk-3) }\end{array}$ & $\begin{array}{l}\text { Higher expressed in ovaries of queen } \\
\text { larvae compared with worker larvae in } \\
\text { fourth and early fifth larvae }\end{array}$ & $\begin{array}{l}\text { (Lago et al. } \\
\text { 2016) }\end{array}$ & Down-regulated & $\begin{array}{l}\text { Up-regulated but } \\
\text { not significantly }\end{array}$ & $\begin{array}{l}\text { Up-regulated but } \\
\text { not significantly }\end{array}$ \\
\hline 408572 & Myophilin (CHD64) & $J H$ response genes & $\begin{array}{ll}\text { (Rewitz et } \\
\text { al. 2006) }\end{array}$ & Down-regulated & $\begin{array}{l}\text { Down-regulated but } \\
\text { not significantly }\end{array}$ & $\begin{array}{l}\text { Up-regulated but } \\
\text { not significantly }\end{array}$ \\
\hline 409881 & $\begin{array}{l}\text { Myosin regulatory light chain } 2 \\
(M l c 2)\end{array}$ & $\begin{array}{l}\text { Up-regulated in mated queens compared } \\
\text { with virgin queens }\end{array}$ & $\begin{array}{l}\text { (Manfredini } \\
\text { et al. 2015) }\end{array}$ & Down-regulated & Down-regulated & $\begin{array}{l}\text { Up-regulated but } \\
\text { not significantly }\end{array}$ \\
\hline 552193 & \begin{tabular}{lll|}
$\begin{array}{l}\text { Proton-coupled amino acid } \\
\text { transporter }\end{array}$ & & \\
\end{tabular} & $Q M P$ response genes & $\begin{array}{ll}\text { Hoover et } \\
\text { al. 2003) }\end{array}$ & Up-regulated & No change & $\begin{array}{l}\text { Down-regulated but } \\
\text { not significantly }\end{array}$ \\
\hline 409681 & $\begin{array}{l}\text { RWD domain-containing protein } \\
1(R W D D 1)\end{array}$ & $Q M P$ response genes & $\begin{array}{l}\text { (Hoover et } \\
\text { al. 2003) }\end{array}$ & Up-regulated & $\begin{array}{l}\text { Down-regulated but } \\
\text { not significantly }\end{array}$ & $\begin{array}{l}\text { Down-regulated but } \\
\text { not significantly }\end{array}$ \\
\hline 409227 & Ultraspiracle (USP) & $E c$ and $J H$ response genes & $\begin{array}{l}\text { (Rewitz et } \\
\text { al. 2006) }\end{array}$ & $\begin{array}{l}\text { Up-regulated } \\
\text { but not } \\
\text { significantly }\end{array}$ & $\begin{array}{l}\text { Down-regulated but } \\
\text { not significantly }\end{array}$ & Up-regulated \\
\hline 406088 & Vitellogenin $(V g)$ & $\begin{array}{l}\text { The protein product serves as a yolk } \\
\text { precursor in egg development }\end{array}$ & $\begin{array}{l}\text { (Nunes et al. } \\
\text { 2013) }\end{array}$ & Down-regulated & Up-regulated & Down-regulated \\
\hline
\end{tabular}

1 


\section{Table 4 (on next page)}

Analysis of DE miRNAs with known or suspected roles in honey bee reproduction or related process.

$V$, group of virgin queens ( $n=3) ; Q$, group of egg-laying queens $(n=3) ; C$, group of egg-laying inhibited queens $(n=3) ; R$, group of egg-laying recovery queens $(n=3)$. 


\begin{tabular}{|c|c|c|c|c|c|}
\hline \multirow[t]{2}{*}{ miRNA id } & \multirow[t]{2}{*}{ Correlate } & \multirow[t]{2}{*}{ Ref. } & \multicolumn{3}{|c|}{ Expression level in this study } \\
\hline & & & Q vs. V & C vs. Q & $\mathrm{R} v s . \mathrm{C}$ \\
\hline Bantam & $\begin{array}{l}\text { Caste determination; target of hippo and EGFR/MAPK signaling } \\
\text { pathways; critical in embryonic development and the control of cell } \\
\text { proliferation and survival; up-regulated in 4-day-old queen larvae } \\
\text { compared with 4-day-old worker larvae; related to insulin and Wnt } \\
\text { pathway. }\end{array}$ & $\begin{array}{l}\text { (Ashby et al. } \\
2016 \text {; Shi et al. } \\
2015 \text { ) }\end{array}$ & Down-regulated & $\begin{array}{l}\text { Up-regulated but } \\
\text { not significantly }\end{array}$ & $\begin{array}{l}\text { Down-regulated } \\
\text { but not } \\
\text { significantly }\end{array}$ \\
\hline Let-7 & $\begin{array}{l}\text { Caste determination; major target of steroid pathways; miRNA markers } \\
\text { associated with the behavioural shift of worker bees from nurses to } \\
\text { forages; immune-related; } V g \text { positive correlation; participated in } \\
\text { regulation of behavioral maturation in honey bees; associated with } \\
\text { reproductive statuses; up-regulated in the inactive ovaries; up-regulated } \\
\text { in 4-day-old queen larvae; related to Wnt pathway; down-regulated in } \\
E c \text { knock down bees }\end{array}$ & $\begin{array}{l}\text { (Ashby et al. } \\
\text { 2016; Macedo et } \\
\text { al. 2016; Mello et } \\
\text { al. 2014; Nunes et } \\
\text { al. 2013; Shi et al. } \\
\text { 2015) }\end{array}$ & Down-regulated & No change & $\begin{array}{l}\text { Up-regulated but } \\
\text { not significantly }\end{array}$ \\
\hline Ame-mir-1 & $\begin{array}{l}V g \text { positive correlation; associated with reproductive statuses; up- } \\
\text { regulated in the inactive ovaries; down-regulated in } E c \text { knock down } \\
\text { bees }\end{array}$ & $\begin{array}{l}\text { (Macedo et al. } \\
\text { 2016; Mello et al. } \\
\text { 2014; Nunes et al. } \\
\text { 2013) }\end{array}$ & Down-regulated & No change & $\begin{array}{l}\text { Down-regulated } \\
\text { but not } \\
\text { significantly }\end{array}$ \\
\hline Ame-mir-10 & Up-regulated in 4-day-old queen larvae & (Shi et al. 2015) & Up-regulated & Down-regulated & $\begin{array}{l}\text { Up-regulated but } \\
\text { not significantly }\end{array}$ \\
\hline Ame-mir-100 & $\begin{array}{l}20 \mathrm{E} \text { and JH response miRNA; caste determination; associated with } \\
\text { reproductive statuses; up-regulated in the inactive ovaries }\end{array}$ & $\begin{array}{l}\text { (Ashby et al. } \\
\text { 2016; Macedo et } \\
\text { al. 2016) }\end{array}$ & Down-regulated & $\begin{array}{l}\text { Down-regulated } \\
\text { but not } \\
\text { significantly }\end{array}$ & $\begin{array}{l}\text { Up-regulated but } \\
\text { not significantly }\end{array}$ \\
\hline Ame-mir-12 & $\begin{array}{l}\text { Associated with reproductive statuses; up-regulated in 4-day-old queen } \\
\text { larvae compared with 4-day-old worker larvae; related to insulin and } \\
\text { MAPK pathway; down-regulated in } E c \text { knock down bees }\end{array}$ & $\begin{array}{l}\text { (Macedo et al. } \\
\text { 2016; Mello et al. } \\
\text { 2014; Shi et al. } \\
\text { 2015) }\end{array}$ & $\begin{array}{l}\text { Down-regulated } \\
\text { but not } \\
\text { significantly }\end{array}$ & Up-regulated & $\begin{array}{l}\text { Down-regulated } \\
\text { but not } \\
\text { significantly }\end{array}$ \\
\hline Ame-mir-125 & $\begin{array}{l}20 \mathrm{E} \text { and } \mathrm{JH} \text { response miRNA; caste determination; up-regulated in the } \\
\text { inactive ovaries; up-regulated in 4-day-old queen larvae compared with }\end{array}$ & $\begin{array}{l}\text { (Ashby et al. } \\
\text { 2016; Macedo et }\end{array}$ & Down-regulated & $\begin{array}{l}\text { Down-regulated } \\
\text { but not }\end{array}$ & $\begin{array}{l}\text { Up-regulated but } \\
\text { not significantly }\end{array}$ \\
\hline
\end{tabular}




\begin{tabular}{|c|c|c|c|c|c|}
\hline & 4-day-old worker larvae; related to insulin, MAPK and mTOR pathway & $\begin{array}{l}\text { al. 2016; Shi et al. } \\
\text { 2015) }\end{array}$ & & significantly & \\
\hline Ame-mir-133 & $\begin{array}{l}\text { Associated with the lipid loss in bees; participated in regulation of } \\
\text { behavioral maturation in honey bees; up-regulated in 4-day-old queen } \\
\text { larvae; related with MAPK pathway; down-regulated in Ec knock } \\
\text { down bees }\end{array}$ & $\begin{array}{l}\text { (Mello et al. } \\
2014 \text {; Nunes et al. } \\
\text { 2013; Shi et al. } \\
2015 \text { ) }\end{array}$ & Down-regulated & No change & $\begin{array}{l}\text { Down-regulated } \\
\text { but not } \\
\text { significantly }\end{array}$ \\
\hline Ame-mir-14 & $\begin{array}{l}\text { Caste determination; negatively related with } E c \mathrm{R} \text { expression and } \\
\text { activity; up-regulated in 4-day-old queen larvae compared with 4-day- } \\
\text { old worker larvae; related to insulin, MAPK, mTOR and Wnt pathway; } \\
\text { down-regulated in } E c \text { knock down bees; up-regulated in the activated } \\
\text { ovaries }\end{array}$ & $\begin{array}{l}\text { (Ashby et al. } \\
\text { 2016; Macedo et } \\
\text { al. 2016; Mello et } \\
\text { al. 2014; Shi et al. } \\
\text { 2015) }\end{array}$ & Down-regulated & No change & $\begin{array}{l}\text { Up-regulated but } \\
\text { not significantly }\end{array}$ \\
\hline Ame-mir-184 & $\begin{array}{l}\text { Stable expression in active and inactive ovary; plays key roles in } \\
\text { embryogenesis; the determination of the anteroposterior axis; embryo } \\
\text { cellularization and stem cell determination; up-regulated in 4-day-old } \\
\text { queen larvae compared with 4-day-old worker larvae; related to insulin } \\
\text { pathway; down-regulated in Ec knock down bees; a miRNA in royal } \\
\text { jelly and affect caste determination }\end{array}$ & $\begin{array}{l}\text { (Guo et al. 2013; } \\
\text { Macedo et al. } \\
\text { 2016; Mello et al. } \\
\text { 2014; Shi et al. } \\
2015 \text { ) }\end{array}$ & Down-regulated & No change & $\begin{array}{l}\text { Down-regulated } \\
\text { but not } \\
\text { significantly }\end{array}$ \\
\hline Ame-mir-190 & Caste determination; immune-related & $\begin{array}{l}\text { (Ashby et al. } \\
\text { 2016) }\end{array}$ & Down-regulated & No change & $\begin{array}{l}\text { Down-regulated } \\
\text { but not } \\
\text { significantly }\end{array}$ \\
\hline $\begin{array}{l}\text { Ame-mir- } \\
252 \mathrm{a}\end{array}$ & $\begin{array}{l}\text { Up-regulated in 4-day-old queen larvae; up-regulated in the activated } \\
\text { ovaries }\end{array}$ & $\begin{array}{l}\text { (Macedo et al. } \\
\text { 2016; Shi et al. } \\
\text { 2015) }\end{array}$ & Down-regulated & $\begin{array}{l}\text { Down-regulated } \\
\text { but not } \\
\text { significantly }\end{array}$ & $\begin{array}{l}\text { Up-regulated but } \\
\text { not significantly }\end{array}$ \\
\hline $\operatorname{miR}-263 a$ & $\begin{array}{l}\text { Associated with reproductive statuses; up-regulated in the inactive } \\
\text { ovaries; down-regulated in } E c \text { knock down bees }\end{array}$ & $\begin{array}{l}\text { (Macedo et al. } \\
\text { 2016; Mello et al. } \\
\text { 2014) }\end{array}$ & Up-regulated & $\begin{array}{l}\text { Down-regulated } \\
\text { but not } \\
\text { significantly }\end{array}$ & $\begin{array}{l}\text { Up-regulated but } \\
\text { not significantly }\end{array}$ \\
\hline Ame-mir-275 & $\begin{array}{l}V g \text { positive correlation; up-regulated in 4-day-old queen larvae; related } \\
\text { to insulin and MAPK pathway }\end{array}$ & $\begin{array}{l}\text { (Nunes et al. } \\
\text { 2013; Shi et al. } \\
\text { 2015) }\end{array}$ & Down-regulated & Up-regulated & $\begin{array}{l}\text { Up-regulated but } \\
\text { not significantly }\end{array}$ \\
\hline
\end{tabular}




\begin{tabular}{|c|c|c|c|c|c|}
\hline Ame-mir-276 & $\begin{array}{l}\text { Associated with reproductive statuses; up-regulated in the inactive } \\
\text { ovaries; down-regulated in } E c \text { knock down bee; up-regulated in 4-day- } \\
\text { old queen larvae compared with 4-day-old worker larvae }\end{array}$ & $\begin{array}{l}\text { (Macedo et al. } \\
\text { 2016; Mello et al. } \\
\text { 2014; Shi et al. } \\
\text { 2015) }\end{array}$ & Down-regulated & Up-regulated & No change \\
\hline Ame-mir-279 & $\begin{array}{l}\text { Caste determination; immune-related; down-regulated in } E c \text { knock } \\
\text { down bees }\end{array}$ & $\begin{array}{l}\text { (Ashby et al. } \\
2016)\end{array}$ & Up-regulated & No change & $\begin{array}{l}\text { Down-regulated } \\
\text { but not } \\
\text { significantly }\end{array}$ \\
\hline $\begin{array}{l}\text { Ame-mir- } \\
2796\end{array}$ & Participated in regulation of behavioral maturation in honey bees & $\begin{array}{l}\text { (Nunes et al. } \\
2013 \text { ) }\end{array}$ & Down-regulated & $\begin{array}{l}\text { Down-regulated } \\
\text { but not } \\
\text { significantly }\end{array}$ & $\begin{array}{l}\text { Down-regulated } \\
\text { but not } \\
\text { significantly }\end{array}$ \\
\hline $\begin{array}{l}\text { Ame-mir- } \\
279 a-3 p\end{array}$ & Up-regulated in the activated ovaries & $\begin{array}{l}\text { (Macedo et al. } \\
2016)\end{array}$ & Down-regulated & $\begin{array}{l}\text { Up-regulated but } \\
\text { not significantly }\end{array}$ & $\begin{array}{l}\text { Down-regulated } \\
\text { but not } \\
\text { significantly }\end{array}$ \\
\hline $\begin{array}{l}\text { Ame-mir- } \\
279 b-3 p\end{array}$ & Up-regulated in the activated ovaries & $\begin{array}{l}\text { (Macedo et al. } \\
2016)\end{array}$ & Up-regulated & No change & $\begin{array}{l}\text { Down-regulated } \\
\text { but not } \\
\text { significantly }\end{array}$ \\
\hline $\begin{array}{l}\text { Ame-mir- } \\
2944-3 p\end{array}$ & Up-regulated in the activated ovaries & $\begin{array}{l}\text { (Macedo et al. } \\
2016)\end{array}$ & Up-regulated & $\begin{array}{l}\text { Down-regulated } \\
\text { but not } \\
\text { significantly }\end{array}$ & $\begin{array}{l}\text { Up-regulated but } \\
\text { not significantly }\end{array}$ \\
\hline Ame-mir-305 & Down-regulated in $E c$ knock down bees & $\begin{array}{l}\text { (Mello et al. } \\
2014)\end{array}$ & $\begin{array}{l}\text { Down-regulated } \\
\text { but not } \\
\text { significantly } \\
\end{array}$ & Up-regulated & $\begin{array}{l}\text { Up-regulated but } \\
\text { not significantly }\end{array}$ \\
\hline Ame-mir-306 & $\begin{array}{l}\text { Associated with reproductive statuses; up-regulated in the activated } \\
\text { ovaries; targets ATPsyn-beta-PA; down-regulated in } E c \text { knock down } \\
\text { bees }\end{array}$ & $\begin{array}{l}\text { (Macedo et al. } \\
\text { 2016; Mello et al. } \\
\text { 2014) }\end{array}$ & Up-regulated & $\begin{array}{l}\text { Down-regulated } \\
\text { but not } \\
\text { significantly }\end{array}$ & $\begin{array}{l}\text { Down-regulated } \\
\text { but not } \\
\text { significantly }\end{array}$ \\
\hline Ame-mir-315 & $\begin{array}{l}\text { Caste determination; modulates tissue patterning and cell } \\
\text { differentiation }\end{array}$ & $\begin{array}{l}\text { (Ashby et al. } \\
2016)\end{array}$ & Up-regulated & $\begin{array}{l}\text { Down-regulated } \\
\text { but not } \\
\text { significantly }\end{array}$ & \begin{tabular}{l}
\multicolumn{2}{l}{ Down-regulated } \\
but not \\
significantly \\
\end{tabular} \\
\hline Ame-mir-316 & $V g$ negative correlation; related to Wnt pathway; down-regulated in $E c$ & (Mello et al. & Down-regulated & Up-regulated but & No change \\
\hline
\end{tabular}




\begin{tabular}{|c|c|c|c|c|c|}
\hline & knock down bees & $\begin{array}{l}\text { 2014; Nunes et al. } \\
\text { 2013) }\end{array}$ & & not significantly & \\
\hline Ame-mir-317 & $\begin{array}{l}\text { Associated with reproductive statuses; up-regulated in the activated } \\
\text { ovaries; related to insulin pathway; down-regulated in Ec knock down } \\
\text { bees }\end{array}$ & $\begin{array}{l}\text { (Macedo et al. } \\
\text { 2016; Mello et al. } \\
\text { 2014) }\end{array}$ & Down-regulated & $\begin{array}{l}\text { Up-regulated but } \\
\text { not significantly }\end{array}$ & No change \\
\hline Ame-mir-31a & $\begin{array}{l}V g \text { negative correlation; associated with reproductive statuses; up- } \\
\text { regulated in the inactive ovaries }\end{array}$ & $\begin{array}{l}\text { (Macedo et al. } \\
\text { 2016; Nunes et al. } \\
\text { 2013) }\end{array}$ & Down-regulated & $\begin{array}{l}\text { Up-regulated but } \\
\text { not significantly }\end{array}$ & $\begin{array}{l}\text { Down-regulated } \\
\text { but not } \\
\text { significantly }\end{array}$ \\
\hline Ame-mir-33 & Caste determination; immune-related & $\begin{array}{ll}\text { (Ashby et al. } \\
\text { 2016) }\end{array}$ & Down-regulated & $\begin{array}{l}\text { Up-regulated but } \\
\text { not significantly }\end{array}$ & No change \\
\hline $\begin{array}{l}\text { Ame-mir- } \\
3718 \mathrm{a}\end{array}$ & $V g$ negative correlation & $\begin{array}{l}\text { (Nunes et al. } \\
2013 \text { ) }\end{array}$ & Down-regulated & No change & $\begin{array}{l}\text { Up-regulated but } \\
\text { not significantly }\end{array}$ \\
\hline Ame-mir-375 & Up-regulated in 4-day-old queen larvae; related to MAPK pathway & (Shi et al. 2015) & Down-regulated & No change & $\begin{array}{l}\text { Up-regulated but } \\
\text { not significantly }\end{array}$ \\
\hline $\begin{array}{l}\text { Ame-mir- } \\
6001-3 p\end{array}$ & Up-regulated in 4-day-old queen larvae & (Shi et al. 2015) & Down-regulated & Not detected & $\begin{array}{l}\text { Up-regulated but } \\
\text { not significantly }\end{array}$ \\
\hline Ame-mir-71 & $\begin{array}{l}\text { Participates in specific steps of the insulin/insulin-like signaling } \\
\text { pathway }\end{array}$ & $\begin{array}{l}\text { (Macedo et al. } \\
2016)\end{array}$ & $\begin{array}{l}\text { Down-regulated } \\
\text { but not } \\
\text { significantly }\end{array}$ & Up-regulated & $\begin{array}{l}\text { Up-regulated but } \\
\text { not significantly }\end{array}$ \\
\hline Ame-mir- 8 & $\begin{array}{l}\text { Caste determination; immune-related; } 20 \mathrm{E} \text { and } \mathrm{JH} \text { response miRNA; } \\
\text { related to Wnt pathway; up-regulated in the activated ovaries }\end{array}$ & $\begin{array}{l}\text { (Ashby et al. } \\
\text { 2016; Macedo et } \\
\text { al. 2016; Shi et al. } \\
\text { 2015) }\end{array}$ & Down-regulated & Up-regulated & No change \\
\hline Ame-mir-92a & $\begin{array}{l}V g \text { negative correlation; participated in regulation of behavioral } \\
\text { maturation in honey bees; associated with reproductive statuses; } \\
\text { down-regulated in } E c \text { knock down bees }\end{array}$ & $\begin{array}{l}\text { (Macedo et al. } \\
\text { 2016; Mello et al. } \\
\text { 2014; Nunes et al. } \\
\text { 2013) }\end{array}$ & Up-regulated & $\begin{array}{l}\text { Down-regulated } \\
\text { but not } \\
\text { significantly }\end{array}$ & No change \\
\hline Ame-mir-92b & $\begin{array}{l}\text { Up-regulated in the activated ovaries; related to insulin, MAPK and } \\
\text { mTOR pathway; down-regulated in } E c \text { knock down bees }\end{array}$ & $\begin{array}{l}\text { (Macedo et al. } \\
\text { 2016; Mello et al. }\end{array}$ & Up-regulated & Down-regulated & $\begin{array}{l}\text { Up-regulated but } \\
\text { not significantly }\end{array}$ \\
\hline
\end{tabular}




\begin{tabular}{|l|l|l|l|l|l|}
\hline & & $\begin{array}{l}\text { 2014; Shi et al. } \\
\text { 2015) }\end{array}$ & (Shi et al. 2015) & $\begin{array}{l}\text { Down-regulated } \\
\text { Ame-mir-993 }\end{array}$ Related to insulin pathway & $\begin{array}{l}\text { Up-regulated but } \\
\text { not significantly } \\
\text { but } \\
\text { significantly }\end{array}$ \\
\hline Ame-mir-996 & Related to insulin pathway & $\begin{array}{l}\text { (Shi et al. 2015) } \\
\text { not }\end{array}$ & $\begin{array}{l}\text { Down-regulated } \\
\text { but } \\
\text { significantly }\end{array}$ & $\begin{array}{l}\text { Up-regulated } \\
\text { not }\end{array}$ & $\begin{array}{l}\text { Down-regulated } \\
\text { but } \\
\text { significantly }\end{array}$ \\
\hline
\end{tabular}

